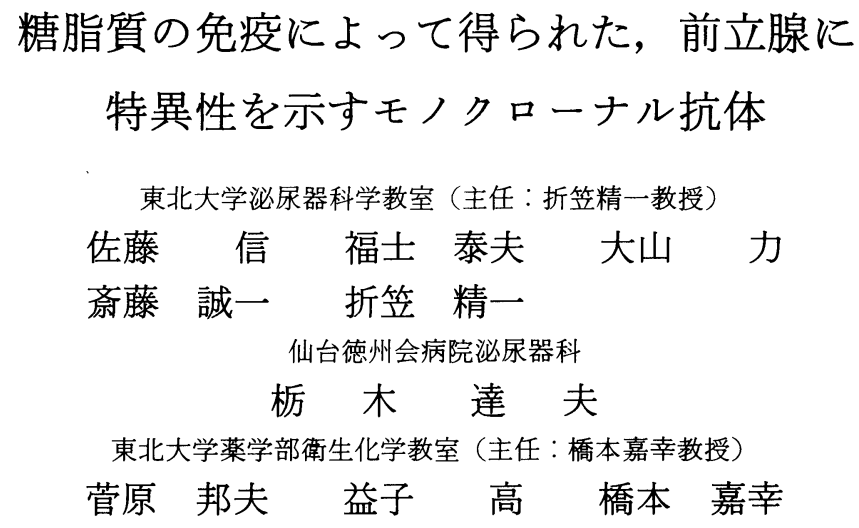

\title{
PROSTATE SPECIFIC MONOCLONAL ANTIBODY GAINED BY GLYCOLIPID IMMUNIZATION
}

\author{
Makoto Satoh, Yasuo Fukushi, Chikara Oyama, Seiichi Saitoh and Seiichi Orikasa \\ Department of Urology, Tohoku University School of Medicine \\ (Director: Prof. S. Orikasa) \\ Tatsuo Tochigi \\ Department of Urology, Sendai Tokusyukai Hospital \\ Kunio Sugawara, Takashi Masuko and Yoshiyuki Hashimoto \\ Department of Hygenic Chemistry, Pharmaceutical Institute, Tohoku University \\ (Director: Prof. Y. Hashimoto)
}

Extraction of glycolipid component from hypertrophic and cancerous prostatic tissue were performed using chroloform-methanol solution and isopropanol-hexan-solution. The extract was separated into the "upper phase" and "lower phase" by Folchs fractionation technic. Each fraction was conjugated with acid treated salmonella minesota and than it was injected subcutaneusly, intraperitonealy and finally intravenously to BALB/c mice. Spleen cells from immunized mice were fused with P3X63, and antibody APG1 was obtained. APG1 shows a preferential reactivity towards prostatic tissue by the immunihistochemical analysis. Furthermore, the immunohistochemical analysis using enzyme and acid treated tissue and TLC immunostaining indicate that this monoclonal antibody specifically recognizes the sialylglycochain expressed in the prostatic tissue.

Key words: monoclonal antibody, glycolipid, prostata

\footnotetext{
要旨：前立腺癌, 前立腺肥大症組織より, クロロホルムーメタノール系, イソプロパノールーヘキサン 一水系を用いて糖腹質分画を抽出した。抽出した糖脂質を Folch 分配法により upper と lower 成分に分 け，そのおのおのを酸処理したサルモネラミネンタと conjugate, BALB/c マウスの皮下と腹腔内に， 最後に尾静脈に注射して免疫した。このマウス脾細胞とマウスミェローマP $3 \times 63$ 細胞融合することに より，前立腺上皮の糖鎖抗原と特異的に反応するモノクローナル抗体 APG1が得られた. APG1(IgG3) は種々のヒト組織を用いた免度組織学的検討から, 前立腺組織に組織特異性を有することが確認された。 また, 前立腺肥大症組織の酵素処理及び酸処理後の染色, さらに前立腺組織から抽出した糖脂質を用 いた TLC-immunostaining の結果より，APG1はシアル酸を含む糖鎖構造を認識することが示唆され た. キーワード：前立腺，モノクローナル抗体，糖脂質
} 


\section{緒言}

疎水性の“セラミド”と親水性の“糖鎖部分”から なる両親媒性の複合糖質である糖脂質が, 細胞表面膜 徽量構成成分として細胞の発生, 分化そして生理活性 物質の受容体機能, 細胞相互間の細胞社会的機能など を担ら重要な物質として注目を集めている1).われわ れもすでに, 腎の分化抗原として存在する糖鎖抗原が, 腎腫瘍の悪性度を反映して消長していることを報告し てきた ${ }^{2) ~ 4)}$. 前立腺疾患に関しては各種のマーカーの 有用性が検討されているが5)，われわれは糖鎖抗原に 着目した. 前立腺肥大症, 前立腺癌組織より抽出した 糖脂質をマウスに免疫, 前立腺組織に存在する糖鎖抗 原に特異的に反応するモノクローナル抗体の作成を試 みた。

\section{実験材料および実験方法}

（前立腺組織より糖脂質の抽出）

前立腺癌全摘標本 2 例（stage C, stage D1）と前立 腺肥大症摘出標本 1 例より, 糖脂質分画を抽出した. 摘出標本にクロロホルムーメタノール系 (CM 1:2,

$\mathrm{CM} 1: 1, \mathrm{CM} 2: 1)$, 及びインプロパノールーヘキサ ン一水系 (IHW $55: 25: 20$ ) を加光, EXCELLAUTO-HOMOGENIZER 用いて, おのおのの液中 で15分× 2 ずつホモジナイズを繰り返し，次いでロー タリーエバポレーターROTAVATOR RE120N で乾 燥させた。これにCM 2：1を加えて溶かし, Folchの 分配法 ${ }^{6)}$ に upper phase と lower phaseに分け，そ れぞれをロータリーエバポレーターで乾燥させた。 そ の後, upper phase は, 蒸留水にて48時間透析を施行 し,さらに凍結乾燥を加え乾燥させた. upper phase の 粗糖脂質は, DEAE-Sephadex A-25カラムを用いてク ロロホルムーメタノールー水系 (CMW 30：60：8), メタノールによりシアル酸を含む酸性糖脂質分画と,

B 液（CM 0.5M sodium acetate $30 ： 60 ： 8$ ）により シアル酸を含まない中性糖脂質分画に分けた ${ }^{7) 8)}$. lower phase は,アセチル化により極性を下げたのち, フロリジールカラムを通して脱アセチル化後, DOWEX50W-X8を用いて pHを $6 〜 7$ に調整し た ${ }^{9)}$.

$$
\text { （ハイブリドーマの作成） }
$$

酸性糖脂質分画と中性糖脂質分画を混ぜ合わせた upper phase と lower phase は，それぞれの抽出時の 標本湿重量 $5 \mathrm{~g}$ に対し, Galanos らの方法10)によってあ らかじめ酸処理した1mgの Salmonella minesotaの PBS 浮遊液を conjugate, $400 \mu 1$ ずつ小チューブに分
注して保存した。これを 1 回 $400 \mu \mathrm{l}$ ずつ, 7 週齢, 雄の $\mathrm{BALB} / \mathrm{c}$ マゥスに 5 日毎に初めの 2 回は皮下と腹腔 内に, 最後の 1 回は静脈内に計 3 回免疫した. 最終免 疫 3 日後に, $50 \%$ ポリエチレングリコール 1, $540 を$ 用 いて脾細胞 $\left(3 \times 10^{7}\right)$ とマウスミェローマ $\mathrm{P} 3 \times 63 \mathrm{Ag}$ $8.653\left(3 \times 10^{5}\right)$ を, 細胞融合させた.

HyMedium 606培地（コージン株式会社）を用いて selectionのあと, 数種のハイブリドーマを得た.

$$
\text { (ハイブリドーマのスクリーニング) }
$$

1. ニトロセルロース膜上でのハイブリドーマの抗 体産生有無の確認

各ハイブリドーマの培養上清を $3 \mu 1$ ずつニトロセル ロース膜上にスポットし，1\%スキムミルクにて室温 で 1 時間ほどブロッキングした。次いで PBS で洗浄 後, rabbit anti mouse Ig (DAKO 社) $1 \%$ BSA-PBS で100倍希釈したものに室温で 1 時間浸し, PBS, 0.05\%Tween PBS, にて 3 回ずつ洗浄. HRP.PA (Horseradish peroxidase 標識 protein A) に室温で 1 時間浸したあと同様に洗浄し，0.01\% $\mathrm{H}_{2} \mathrm{O}_{2}, 0.25 \mathrm{mg} /$ ml DABを用いて免疫染色した。

2. 八イブリドーマ産生抗体と糖脂質との反応 前立腺組織より抽出した糖脂質を, 抽出時標本湿重 量 $\lg$ あたりクロロフォルム：メタノール $=2: 1$ の 液 $1 \mathrm{ml}$ に溶解し, その3ul ずつをニトロセルロース膜 にスポットし抗原とした。次いで $1 \%$ 次ムミルクで 室温 1 時間, ブロッキング後，1．で抗体産生が確認 されたハイブリドーマの培養上清を $3 \mu 1$ ずつ抗原ス ポット上に乗せ, 室温で 1 時間反応させた. PBS $0.05 \%$ Tween PBS で洗浄後, 1. と同様の手順で rabbit anti mouse Ig, HRP-PA, $0.01 \% \mathrm{H}_{2} \mathrm{O}_{2} 0.25 \mathrm{mg} /$ ml DAB を用いて発色させた。

3. 免疲組織化学的スクリーニング

病理解剖あるいはTUR-Pで得られた前立腺癌組 織, 前立腺肥大症組織, 正常前立腺組織の薄切凍結切 片による組織標本を作成した。切片は, 室温にてアセ トン（5 分）固定， $1 \%$ スキムミルク 1 昼夜ブロック 後, 糖脂質との反応が確認されたハイブリドーマ培養 上澄みを 1 時間反応させ, 洗浄後ビオチン化抗マウス Ig ウサギ血清, 続いて AB complex (Vector) と 1 時 間ずつ反応させ， $0.01 \% \mathrm{H}_{2} \mathrm{O}_{2}, 0.25 \mathrm{mg} / \mathrm{ml} \mathrm{DAB} に て$ 発色させた。

$$
\text { (ハイブリドーマのクローンニング) }
$$

96well plateを用いて, 限界希釈法 (Iimiting dilution method）にてクローン化を行った（図 1 ). 
図 1 Immunization method

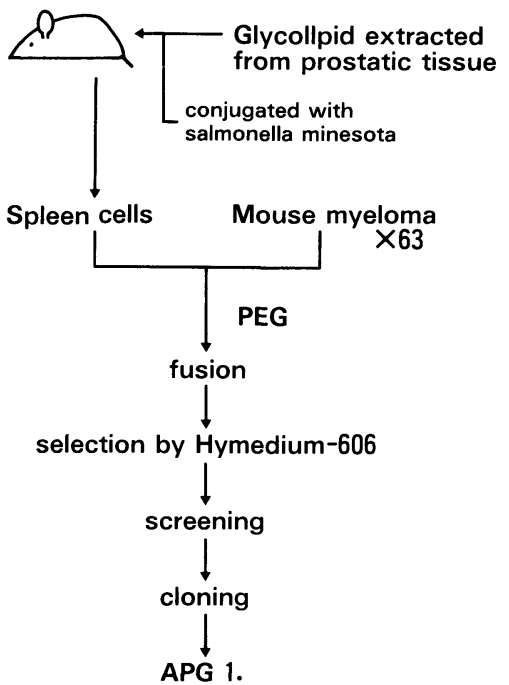

（免疫染色）

1. 培養細胞の免疫染色

KU 1 (ヒト膀脱癌の培養系) ${ }^{11}$, MKN 7 (ヒト胃癌 の培養系) ${ }^{12)}$, A431 (ヒト子宮癌の培養系), MethA (BALB/c マウス由来の繊維芽肉腫の培養系), $\mathrm{HCV}$ 29 (ヒト正常膀胱粘膜の培養系), PC 3 (ヒト前立腺癌 の培養系) ${ }^{13)}$, 以上の細胞を $5.0000 / \mathrm{ml}$ になるように希 釈，テラサキプレートに $20 \mu \mathrm{l} / \mathrm{well}$ ずつまき $12 \sim 24$ 時 間培養した. PBSにて洗浄後, アセトンーメタノール 1：1溶液にて 5 分間固定した. PBS にて 3 回洗浄後

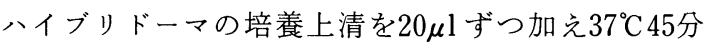
間反応させた，次いで 2 次抗体として $1 \%$ BSA-PBS で100倍希釈した FITC 標識抗マウス Ig $20 \mu 1$ ずつ加 え, 遮光して 45 分間 $37^{\circ} \mathrm{C}$ で反応させた. $\mathrm{PBS}$ で洗浄後, 蛍光顕微鏡で観察した。

2. 種々のヒト組織に対する免疫組織染色

凍結切片，あるいらパラフィン切片を用いたが，凍 結切片は, 前述と同様にして行った。 パラフィン切片 は, キシレンで $5 \min \times 3$ 回為パラ後エタノール系にて 脱出し，スキムミルクによるブロック後は凍結切片と 同様に行った.いずれの染色も, 内因性ペスオキシダー ゼ除去のため $0.3 \%$ 過酸化水素メタノールによる処理 を 5 分間, 培養上清による反応後に追加した。

（抗体認識抗原の性状解析）

1. 酵素処理, 過ヨウ素酸ナトリウム処理による免疫 組織化学的検討での認識抗原の性状解析

前立腺肥大症組織の凍結薄切片を 5 分間アセトンに
て固定し，下記の処理をした後，ABC 法 (Vector)で 免疫染色した。

a) ノイラミニダーゼ (半井化学) $0.25 \mathrm{unit} / \mathrm{ml}$ と, $\mathrm{pH} 5.5,20 \mathrm{mMol}$ acetate buffer 中で $37^{\circ} \mathrm{C} 1$ 時間反応 させる。

b）上記に，0.05\%濃度になるようにコール酸を加 えたものと反応させる。

c）コントロールとして $20 \mathrm{mMol}$, acetate buffer $\mathrm{pH}$ 5.5 のみにて, $37^{\circ} \mathrm{C} 1$ 時間反応させる.

d）酸処理として， $\mathrm{NalO}_{4}$ を $5 \mathrm{mMol}$ の濃度にした PBS buffer 中で, $4{ }^{\circ} \mathrm{C} 1$ 時間反応させる.

2. HPTLC上でのラジオイムノステイニング

正常前立腺組織, 前立腺肥大症組織, 前立腺癌組織 より抽出した糖脂質を, 抽出前湿重量換算で upper phaseは0.2g, lower phaseは0.1gをべーカー製 HPTLCプレート上にスポットした。

upper phase $は$, ganglioside fraction, neutral fractionに関し, 各々 $\mathrm{C}: \mathrm{M}: 0.5 \% \mathrm{CaCl}_{2}=60: 40: 9$ に て展開, Lower phase は C : M : W=60：25：9にて 展開した。 $5 \%$ BSA (0.05\%PBS pH 7.4) 内に浸し て， 2 時間ブロッキング後，APG 1を 1 昼夜反応させ た. $5 \% \mathrm{BSA}(0.05 \% \mathrm{PBS} \mathrm{pH} 7.4)$ にて, ゆっくり 摇らしながら， $5 \min \times 5$ 回洗浄した後, rabbit anti mouse Ig に浸し室温で 2 時間反応させた. 同様に洗浄 後, ${ }^{125}$ I-protein A に浸し 1 時間反応させた. 乾燥後, $\mathrm{X}$ 線フィルムを重ね, 暗箱内で 2 昼夜露光し現像し た。

3. 糖脂質分画とAPG1の ELISA による検討

前立腺肥大組織より抽出した, 糖脂質の upper phase の ganglioside, neutral の各 fraction に関し, 抽出時湿重量 $5 \mathrm{mg}$ 換算量を $50 \mu 1$ のエタノールに溶解, 96穴塩化ビニール平底プレートに固相化，各ウェルを $1 \%$ \%キムミルクにて，ブロッキングを 1 時間施行し た. 以下洗浄は, PBS にて 3 回, Tween PBS にて 3 回行いながら，APG 1培養上清(室温 1 時間)，ペルオ キシダーゼ標識抗マウス Ig ウサギ血清(室温 1 時間) を順次加え, OPD $(0.4 \mathrm{mg} / \mathrm{ml}$, O-phenylenediamine/ $0.1 \mathrm{M}$ citrate-phosphate buffer pH 5.0,0.01\% $\mathrm{H}_{2} \mathrm{O}_{2}$ ) (SIGMA 社)で発色させた. 反応は $1 \mathrm{~N}$ 硫酸にて停止さ せ, EIA Reader (EASY READER EAR400) で492 $\mathrm{nm}$ における吸光度を測定した。

\section{結果}

1. ハイブリドーマのスクリーニング

糖脂質の免疫で得られたハイブリドーマのらち，特 
表 1 Reactivity to cultured cell

\begin{tabular}{c|c|c}
\hline Cell line & APG 1 & FH6 $^{3)}$ \\
\hline A431 (uterine tumor) & - & + \\
KU 1 \\
$\begin{array}{c}\text { (bladder tumor) } \\
\text { MKN7 } \\
\text { (gastric cancer) }\end{array}$ & - & ++ \\
$\begin{array}{c}\text { HCV29 } \\
\text { (normol bladder) }\end{array}$ & - & ++ \\
$\begin{array}{c}\text { PC 3 } \\
\text { (prostatic tumor) }\end{array}$ & - & - \\
$\begin{array}{c}\text { MethA } \\
\text { (fibrosarcoma } \\
\text { mouse BALB/C) }\end{array}$ & - & - \\
\hline
\end{tabular}

表 2 APG 1 Reactivity to tissues

TCC: transitional cell carcinoma, wel : 高分化腺 癌, $\bmod ：$ 中分化腺癌, por：低分化腺癌

\begin{tabular}{l|c}
\multicolumn{1}{c|}{ Tissues } & Positive rate \\
\hline normal prostata (frozen section) & $2 / 2$ \\
prostata hypertrophy (frozen section) & $5 / 5$ \\
prostata hypertrophy & $7 / 7$ \\
prostata carcinoma (wel) & $1 / 2$ \\
prostata carcinoma (mod) & $0 / 2$ \\
prostata carcinoma (por) & $0 / 4$ \\
normal bone marrow & $0 / 2$ \\
nomal liver & $0 / 4$ \\
normal spleen & $0 / 4$ \\
normal bladder & $0 / 3$ \\
bladder tumor (TCC grade3) & $0 / 3$ \\
nörmal intestine & $0 / 4$ \\
normal lung & $0 / 4$ \\
lung tumor (small cell carcinoma) & $0 / 2$ \\
normal pituitary gland & $0 / 2$ \\
normal stomach & $0 / 3$ \\
normal spleen & $0 / 4$ \\
normal pancreas & $0 / 4$ \\
esophageal cancer & $0 / 2$ \\
normal colon & $0 / 4$ \\
normal testis & $0 / 4$ \\
testicular tumor & $0 / 3$ \\
(embryonal carcinoma with seminoma) & $0 / 3$ \\
renal tumor & $0 / 4$ \\
\hline & \\
& \\
\hline
\end{tabular}

に upper phase で得られた153株中 2 株に抽出した糖 脂質と前立腺組織に反応が得られた。このらち，後に 述べる免疫組織学的検索により前立腺上皮に特異的に 反応したものを APG1とした。サブクラスは IgG3で あった。

\section{2. 各種培養細胞との反応}

アセトンーホルマリン固定の染色で 6 種類の培養細 胞との反応を検討したが，染色陽性株は 1 例も認めら れなかった（表 1).

3. 免疫組織化学的反応

前立腺肥大症組織, 高分化の前立腺癌組織, 正常前
表 3 (Neuraminidase, $\mathrm{NaIO}_{4}$ ) treatment of $\mathrm{BPH}$ tissue

\begin{tabular}{c|c}
\hline Treatment & Reactivity \\
\hline $\begin{array}{c}\text { Neuraminidase }+\mathrm{Na} \text { acetate buffer } \\
+\mathrm{Na} \text { cholate acid } \\
\text { Neuraminidase }+\mathrm{Na} \text { acetate buffer }\end{array}$ & - \\
$\mathrm{Na}$ acetate buffer & + \\
$\mathrm{NaIO}_{4}$ & - \\
$\mathrm{No}$ treatment & + \\
\hline
\end{tabular}

立腺組織の腺上皮は, apical portion (腺腔内腔面)の 部分の細胞膜が特に強く, 細胞質全体も淡く染まり, 腺上皮以外の部分には，反応を示さなかった。

分化度の低い前立腺癌では反応性が認められず，前 立腺以外の正常組織, 腫瘍組織にも反応性は認められ なかった。

また, 前立腺肥大症組織で, 凍結切片に比ベパラフィ ン切片では反応性が弱かった（図 2, 表 2).

4. 抗体認識抗原の性状解析

1）前立腺肥大症組織の過ヨウ素酸 $\mathrm{Na}$ 処理, ノイラ ミニダーゼ処理によって，その染色性は失われた. $\mathrm{pH}$ 5.0 の酸処理のみでは, 染色性に, 変化は認められな かった（表 3 ).

2) HPTLC 上でのラジオイムノアッセイ

正常前立腺, 前立腺肥大症, 前立腺癌の各組織の ganglioside fraction の GD3付近のバンド以下に数本 の反応が認められた（図 3 ）.

3）抽出した糖脂質と APG 1の ELISA での検討

前立腺肥大症より抽出した糖脂質のらち, ganglioside fractionにのみ, その反応性が認められた。

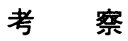

近年，腫煌マーカーの多くが，そのエピトープを糖 鎖構造に有していることがあきらかとなってきた。泌 尿器科領域に括いても, 従来, ALP, AFP, 胎盤性 ALP, HCG, $\beta \mathrm{HCG}$ 等, いくつかの腫瘍マーカーが用 いられ前立腺に関しても ACP, PAP， $\gamma \mathrm{sm}$ 等がある. しかし，これらの多くが蛋白部分にェピトープを有す る抗原と考兄られ，前立腺に抢ける糖鎖の変化を抗原 として捕えた研究は，ほとんど認められない(14)。われわ れは, 糖鎖抗原が, 泌尿器系藏器の分化や癌化にとも ない大きく变化するといら事実に着目し，まず前立腺 における糖鎖の発現パターンを調べるとともに, これ に対するモノクローナル抗体の作成を研究の第一段階 とした. 
図 2 ヒト前立腺肥大症組織の $\mathrm{ABC}$ 染色：腺腔内腔面の細胞膜が特に強く, 細胞質 全体も淡く染色されている。（×100）

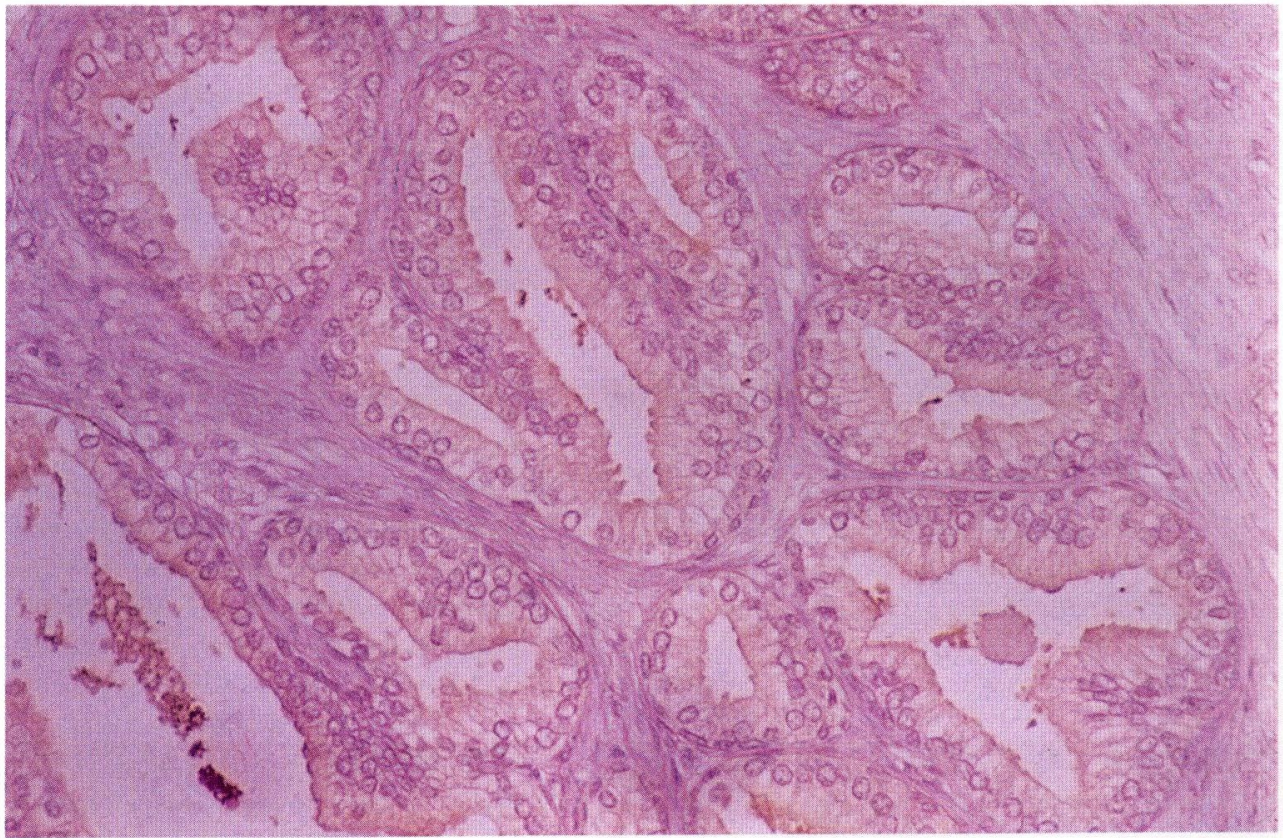

図 3 TLC-immunostaining

Normal：正常前立腺, $\mathrm{PH}$ ：前立腺肥大症, $\mathrm{PK}$ ：前立腺癌

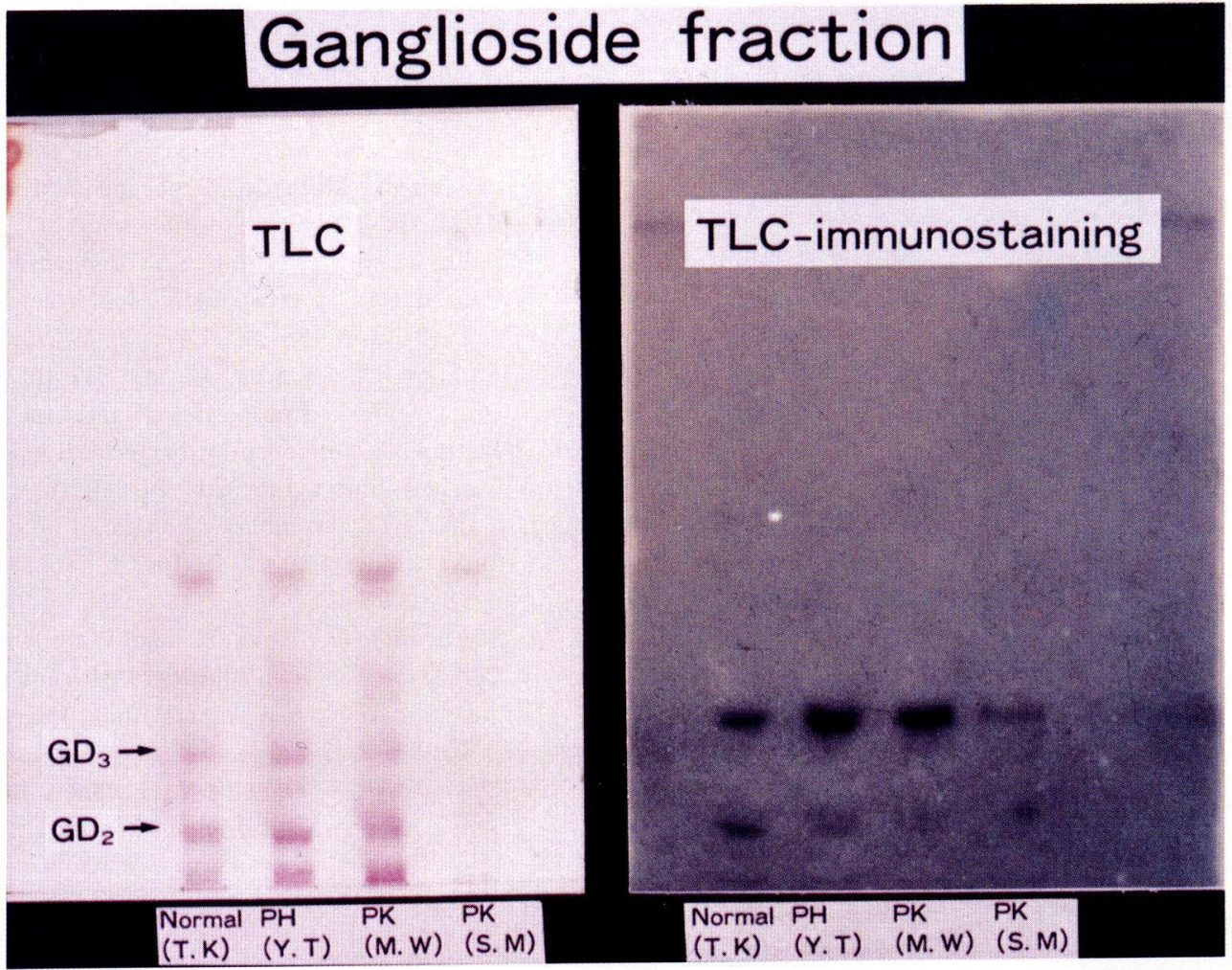


糖鎖抗原としては，糖脂質を前立腺組織より抽出し て用いた．糖鎖に対するモノクローナル抗体を効率よ く作成するため, 抽出した糖脂質を直投免疫源として 用いた ${ }^{15)}$ 。

得られた抗体のスクリーニングは, crude な糖脂質 に対する反応である程度分別したあと，最終的には組 織に対する反応を重視した。この方法によりほぼ間違 いなく糖鎖を認識する抗体を得ることができる。

得られた抗体 APG 1 （IgG 3）は，ヒト前立腺に対 する藏器特異性を有する抗体であると考えられた。さ らに前立腺に対する陽性反応が，パラフィン切片では 極端に減弱することから，糖脂質抗原が染色過程のお そらく加水の段階で，失われるものと考兄られ，本抗 体によって認識される糖鎖は，糖蛋白よりも主として 糖脂質として存在する可能性が高いと考えられた。

そこで，この M-Ab が認識する抗原エピトープにつ いてさらに詳細な検討を加えた。まず，過ヨウ素酸処 理で抗原性が消失することは，糖鎖抗原がェピトープ であることを裏付ける結果であった。また，neur aminidaze によっても反応性が消失することから，抗 原は認識される構造中にシアル酸を有することがうか がえる。この点は HPTLC プレート上に展開した糖脂 質のうち, immunostainingによって, ganglioside fraction の一部に抗体が, 反応することとも一致する. 以上の結果から, この抗体の認識する抗原は, 前立腺 組織特異性を有する ganglioside であろうと考えられ る。また，糖脂質に主として存在するとすれば， ganglio-series に属する ganglioside であろうと考兄 られる，今後，抗原の同定についても検討を進める必 要があろらと思われた. ganglioside は従来, 細胞の分 化，成長及び腫瘍の悪性度と深くかかわりを有してい ることが知られている ${ }^{16)}$. 今回得られた M-Ab の反応 性は，正常前立腺，前立腺肥大症，高分化型の前立腺 癌においてょり強く認められており，この抗原は前立 腺の分化抗原として出現している可能性が高い17)。こ の点は今後, 多くの前立腺癌において検討を重ねるこ とにより, 病理的分化度, あるいはホルモン依存性の 有無との関連において大いに興味のもたれる研究課題 である。

\section{結 語}

1. 前立腺組織より抽出した糖脂質を抗原として, mouse モノクローナル抗体 APG 1を作製した。

2. APG 1は前立腺に特異的に分布する, シアル酸を 含む糖鎖構造を認識することが示唆された。
稿を終えるにあたり，組織標本を，提供していただいた， 東北大学病理部の皆様に深謝致します。なお, 本論文の要旨 は第47回日本癌学会総会に扔いて報告した。

\section{文献}

1) Hakomori, S.: Glycosphingolipids. Sci. Am., 254, 32-41, 1986.

2) Fukushi, Y., Nudelman, E., Levery, S.B. and Hakomori, S.: Novelfucolipids accmulating in human adenocarcinoma. J. Urol., 259, 10511 $-10517,1984$.

3）福士泰夫, 斎藤誠一, 折笠精一：腎細胞癌に抢ける $\mathrm{Le}^{\mathrm{x}}$ (SSEA-1)抗原群の発現：腫瘍分化度及び予 後との相関についての検討. 日泌尿会誌, 79, 1090-1095, 1988.

4) Fukushi, Y., Ohtani, H. and Orikasa, S.: Experssion of lacto series type 2antigens in human renal cell carcinoma and its clinical significance. JNCl., 81, 352-358, 1989.

5）秋元 晋, 赤倉功一郎, 島崎 淳：前立腺癌におけ る腫瘍マーカー(前立腺酸性フォスファターゼ, $\gamma$. セミノプロティン, 前立腺特異抗原)の検討. 泌尿 紀要， 34，1389，-1396，1988.

6) Folch, J., Lees, M. and Sloane Stanley, G.H. : A simple method for the isolation and purification of total lipides from animal tissues. J. Biol. Chem., 226, 497-509, 1957.

7) Ledeen, R.W. and Yu, R.K.: Gangliosides: structure, isolation, and analysis. Method Enzymol., 83, 139-191, 1982.

8) Laine, R.A., Stellner, K. and Hakomori S.: Isolation and characterization of membrane glycolipids. Methods Membrane Biol., 2, 205 $-224,1974$.

9) Saito, T. and Hakomori, S.: Quantitive isolation of total glycosphingolipids from animal cells. J. Lipid. Res., 12, 257-259, 1971.

10) Galanos, C., Luderitz, O. and Westphal, O.: Preparation and properties of antisera against the lipid-A component of bacterial lipopolysaccharides. Eur. J. Biochem., 24, 116-122, 1971.

11) Yajima, T.: Monolayer culture of human urinary bladder tumors. II. Jpn. J Urol., 61, 805 $-831,1970$.

12) Motoyama, T., Hojo, H. and Watanabe, H.: Comparison of 7cell lines derived from human gastric carcinomas. Acta Pathol. Jpn., 36, 65 $-83,1986$

13) Narayan, K.S., Ohnuki, Y., Lechner, J.F. and Jones, L.W.: Establishment and characterization of a human prostatic carcinoma cell line (PC3). J. Urol., 17, 16-23, 1979. 
14) Hakomori, S.: Aberrant glycosylation in cancer cell membrane as focused on glycolipids : Overview and perspectives. Cancer Res., 45, 2405-2411, 1985.

15）福士泰夫, 阿部和夫：糖脂質に対するモノクロー ン抗体その 1.モノクローン抗体の作製, 蛋白質. 核酸酵素, 32, 1363-1370, 1987.

16) Nojiri, H., Takaku, F., Terui, Y., Miura, Y., Saito, M.: Ganglioside GM3: Anacidic mem- brane component that increases during macrophage-like cell differentiation can dnduce monocytic differentiation of human myeloid and monocytoid leukemic cell lines HL-60 and U937. Proc. Natl. Acad. Sci., 83, 782-786, 1986.

17）福土泰夫：腫瘍組織から抽出した糖鎖構造を認識 するモノクローナル抗体. BoOmedia, 2, 61-65, 1987.

（1989年11月 2 日受理） 